\title{
PEMERIKSAAN KUALITAS MUTU DAN CEMARAN MIKROBIOLOGI IKAN PINDANG LAYANG (Decapterus spp) di PASAR MAMBAL, BALI
}

\section{THE EXAMINATION OF QUALITY AND MICROBIOLOGICAL CONTAMINATION OF PINDANG LAYANG FISH (Decapterus spp) in MAMBAL MARKET, BALI}

\author{
I GUSTI PUTU AGUS FERRY SUTRISNA PUTRA ${ }^{1 *}$, I K. PUTRA JULIANTARA ${ }^{1}$, \\ NI LUH PUTU ARI SUKMAYANTI ${ }^{1}$, DEWI PUSPITA APSARI ${ }^{2}$ \\ ${ }^{1}$ Program Studi Teknologi Laboratorium Medik, Institut Ilmu Kesehatan Medika Persada Bali \\ ${ }^{2}$ Program Studi Farmasi, Institut Ilmu Kesehatan Medika Persada Bali
}

\begin{abstract}
Abstrak: Ikan dan produk perikanan merupakan bahan pangan yang mudah rusak dan membusuk. Di Bali, ikan pindang merupakan salah satu makanan yang digemari dan mudah ditemukan di pasar. Masyarakat kalangan menengah kebawah umumnya lebih memilih pasar tradisional sebagai tempat untuk berbelanja. Salah satu pasar tradisional yang selalu ramai pembeli dan menyediakan ikan pindang di Bali adalah pasar Mambal. Pasar Mambal merupakan pasar yang terletak di Desa Mambal, Kabupaten Badung, Bali. Penelitian ini merupakan penelitian deskriptif yang bertujuan untuk mengetahui ada tidaknya cemaran bakteriologis pada ikan pindang (Decapterus spp) di Pasar Mambal, Badung, Bali dengan desain penelitian one shot case study. Dari 30 sampel yang diperiksa diperoleh jumlah MPN Escherichia coli melebihi nilai standart kualitas ikan pindang dari SNI 01-2717-2009 (Tidak memenuhi syarat). Jumlah MPN Escherichia coli ikan pindang di bawah nilai standart maximum yang di ijinkan oleh SNI 01-2717-2009 yaitu < 3 APM/gram Ikan Pindang (memenuhi syarat). Pada pemeriksaan Angka Lempeng Total juga ada didapat hasil yang melebihi batas maksimal yang ditentukan pada SNI 01-2717-2009 dimana batas maksimal yang diperbolehkan yaitu 5 x $10^{5}$ CFU per gram bahan. Ikan pindang yang diperiksa memiliki kualitas yang tidak baik dan tidak memenuhi syarat sesuai SNI 01-2717-2009 yang menyatakan bahwa jumlah bakteri Escherichia coli dalam ikan pindang adalah < 3 APM per gram bahan dan jumlah maksimal ALT ikan pindang adalah 5 x $10^{5} \mathrm{CFU}$ per gram. Ikan pindang yang diperiksa kulitas mutunya (Rasa, Rupa, bau, Warna, dan Tekstur) memiliki kualitas yang tidak baik.
\end{abstract}

Kata kunci: Ikan pindang, MPN, Escherichia coli, Angka Lempeng Total

\begin{abstract}
Fish and fishery products are fragile and decaying foodstuffs. In Bali, pindang fish is one of the favorite foods and easily found in the market. The middle class people generally prefer the traditional market as a place to shop. One of the traditional market that have alot of buyers and provide pindang fish in Bali is Mambal market. Mambal Market is a market which located in Mambal Village, Badung regency, Bali. This research is a descriptive research that aims to find out whether or not bacteriological contamination of the pindang fish (Decapterus spp) in Mambal Market, Badung, Bali with one shot case study design study. From 30 samples examined, the amount of MPN Escherichia coli exceeded the standard quality of pindang fish from SNI 01-2717-2009 (Unqualified). The amount of MPN Escherichia coli of pindang fish is below the maximum standard allowed by SNI 01-2717-2009 ie <3 APM / gram pindang fish (eligible). In the Total Plate Number examination there is also obtained results that exceed the maximum limit specified in the SNI 01-2717-2009 where the maximum limit is 5 x $105 \mathrm{CFU}$ per gram of material. Pindang fish examined has a bad quality and does not fulfill the requirements of SNI 01-2717-2009 which states that the amount of Escherichia coli bacteria in pindang fish is $<3$ APM per gram of material and the maximum amount of ALT of pindang fish is $5 \times 105$ CFU per gram. Pindang fish that checked of this examination (Flavor, Form, Smell, Color, and Texture) doesn't have a good quality,.
\end{abstract}

Keywords: Pindang kite fish, MPN, Escherichia coli, Total Plate Number

\section{PENDAHULUAN}

Pangan merupakan kebutuhan pokok manusia yang diperlukan sebagai sumber gizi untuk tubuh. Manusia membutuhkan berbagai asupan gizi untuk tubuh, salah satunya adalah protein yang berperan sebagai sumber energi. Bahan makanan dengan protein tinggi banyak

\footnotetext{
* email korespondensi: ferry.vikana@gmail.com
} 
terdapat pada makanan asal hewan seperti ikan. Bahan pangan ikan merupakan sumber asam lemak tak jenuh, taurin dan asam lemak omega-3. Komponen tersebut telah terbukti dapat mencegah penyumbatan pembuluh darah (arteriosclerosis), oleh karena itu banyak orang berpendapat untuk meningkatkan konsumsi protein harian (daily protein intake) terutama yang berasal dari ikan (Winarni dkk, 2003).

Ikan dan produk perikanan merupakan bahan pangan yang mudah rusak dan membusuk jika tidak ditangani dengan baik karena ikan mengandung protein dan kadar air cukup tinggi. Proses pembusukan atau kemunduran mutu pada ikan dapat terjadi karena adanya aktivitas enzim, mikroorganisme ataupun oleh peristiwa biooksidasi lemak (Darmanto YS, 2001). Kandungan tersebut sangat baik untuk pertumbuhan mikroorganisme sehingga perlu dilakukan perlakuan pascapanen yang benar pada ikan setelah ikan tertangkap untuk mencegah kemunduran mutu ikan (Wirakusumah, 2010).Standar mutu ikan berdasarkan SNI tahun 2009 yaitu dari segi organoleptik minimal 7, dan dari segi mikrobiologi maksimal koloni/gram TPC ikan pindang yaitu $5 \times 10^{5}$ dan MPN Escherichia coli yaitu maksimal 3APM/gram (SNI, 2009).

Bali merupakan salah satu kota besar di Indonesia yang memiliki jumlah penduduk tinggi. Di Bali, ikan pindang merupakan salah satu makanan yang digemari dan mudah ditemukan di pasar. Masyarakat kalangan menengah kebawah umumnya lebih memilih pasar tradisional sebagai tempat untuk berbelanja. Salah satu pasar tradisional yang selalu ramai pembeli dan menyediakan ikan pindang di Bali adalah pasar Mambal. Pasar Mambal merupakan pasar yang terletak di Desa Mambal, Kabupaten Badung, Bali. Dilihat dari segi kebersihan, pasar ini memiliki tingkat higenitas yang rendah sehingga mutu pangan yang dijual disana berbeda dengan mutu pangan yang dijual di pasar modern dimana pangan yang dijual disimpan dalam tempat yang steril dengan suhu yang sesuai untuk penyimpanan.

Berdasarkan uji pendahuluan yang dilakukan pada Oktober 2017 di laboratorium Mikrobiologi IIK Bali pada 10 sampel ikan pindang layang yang diambil dari pasar mambal secara acak ditemukan adanya pertumbuhan Escherichia coli pada 8 sampel uji. Dari uraian diatas, peneliti akan melakukan penelitian untuk mengetahui mutu ikan pindang layang secara mikrobiologis di Pasar Mambal, Badung, Bali.

\section{METODE}

Penelitian ini merupakan penelitian deskriptif yang bertujuan untuk mengetahui kualitas mutu hasuil pemindangan dan cemaran bakteriologis pada ikan pindang layang (Decapterus spp) di Pasar Mambal, Badung, Bali dengan desain penelitian one shot case study.

Bahan Penelitian. Bahan dari peneltian ini adalah Ikan Pindang Layang diambil secara acak dari 6 tempat di Pasar Mambal. Setiap tempat masing-masing diambil 5 sampel Ikan pindang layang. Sehingga total jumlah sampel adalah 30 sampel, Lactosa Broth Singgle Strength (LBSS), Lactosa Broth Triple Strength (LBTS), Brillian Grameen Lactosa Bile Broth (BGLBB), Media Plate Count Agar (PCA), $\mathrm{NaCl}$ fisiologis steril, Aquadest.

Instrumen Penelitian. Alat-alat yang digunakan dalam penelitian ini adalah pipet ukur volume 10 $\mathrm{ml}, 1 \mathrm{ml}$, dan $0,1 \mathrm{ml}$, lampu spritus, tabung reaksi dan rak tabung, inkubator, oven, ose, timbangan, pipet automatic $1000 \mathrm{~m} \mu$, tip kuning, labu erlenmeyer $250 \mathrm{ml}$, cawan petri steril, hand counter, dan pisau. Hal yang perlu diperhatikan seluruh alat yang digunakan harus dibersihkan dan disterilkan.

\section{Prosedur Penelitian}

a. Sterilisasi alat

Semua peralatan yang akan digunakan dibersihkan dan disterilisasi dengan dibungkus kertas coklat kemudian dimasukkan kedalam oven dengan suhu $180^{\circ}$ C selama 2 jam.

b. Pembuatan Media

1) MPN

a) Lactosa Broth Singgle Strength ( LBSS )

Komposisi :

$\begin{array}{ll}\text { Nutrien Broth } & : 4 \text { gram } \\ \text { Lactosa } & : 5 \text { gram } \\ \mathrm{NaCl} & : 2,5 \text { gram } \\ \text { Aquadest } & : 500 \mathrm{cc}\end{array}$

Bahan dipanaskan hingga larut kemudian diisikan ke dalam tabung reaksi masingmasing $10 \mathrm{ml}$ ditambah dengan tabung Durham, kemudian disterilkan dengan autoclave pada suhu $121^{\circ} \mathrm{C}$ selama 15 menit.

b) Lactosa Broth Triple Strength ( LBTS )

Komposisi :

Nutrien Broth : 10,0 gram / liter

Lactosa $\quad: 10,0$ gram / liter 
Brillian Green : 0,0133 gram / liter

Di campur kemudian diisian kedalam tabung reaksi masing-masing $10 \mathrm{cc}$ ditambah dengan tabung Durham, kemudian di sterilkan dengan autoclave pada suhu $121^{\circ} \mathrm{C}$ selama 15 menit.

c) Brillian Green Lactosa Bile Broth ( BGLBB ) Komposisi ( Dalam bentuk kit ) :

1. Pepton $: 10,0$ gram / liter

2. Lactosa $: 10,0$ gram / liter

3. Brillian Green : 0,0133 gram / liter

Dilarutkan 40 gram / liter BGLB, dimasukkan dalam tabung reaksi berisi tabung Durham, kemudian disterilkan dengan Autoclave pada suhu $121^{\circ} \mathrm{C}$ selama 15 menit (BPOM RI,2008)

2) Angka Lempeng Total

a) Media Plate Count Agar (PCA)

Media untuk pemeriksaan jumlah angka kuman adalah media Plate Count Agar (PCA) dengan komposisi :

Tripton 5 gram, ekstrak khamir 1,5 gram, dekstrosa 1 gram, agar 15 gram, dan aquadest $1000 \mathrm{ml}$. Semua komposisi tersebut dicampur, dipanaskan dalam waterbath sampai semua bahan larut. Mulut labu Erlenmeyer ditutup kapas kemudian disterilkan dalam autoclave pada $121^{\circ} \mathrm{C}$ selama 15 menit.

b) $\mathrm{NaCl}$ fisiologis steril $(\mathrm{NaCl} 0,85 \%$ steril) Dilarutkan 0,85 gram $\mathrm{NaCl}$ dalam $100 \mathrm{ml}$ aquadest steril. Lalu disterilkan dalam autoclave $121^{\circ} \mathrm{C}$

c. Prosedur Pemeriksaan Most Probable Number (MPN)

1) Pengenceran sampel

Masing-masing sampel ikan pindang ditimbang sebanyak 10 gram dalam labu Erlenmeyer steril, kemudian ditambah larutan $\mathrm{NaCl}$ fisiologis sampai volume $100 \mathrm{ml}$.

2) Cara kerja pemeriksaan sampel MPN

a) Uji Pendahuluan.

Sampel ikan yang telah diencerkan ditanam pada media :

1. 5 Tabung media triple Strength masingmasing $10 \mathrm{ml}$

2. 1 Tabung media singgle strength $1 \mathrm{ml}$

3. 1 Tabung media singgle strength $0,1 \mathrm{ml}$

4. Diinkubasi pada suhu $37^{\circ} \mathrm{C}$ selama $2 \times 24$ jam

5. Diamati kekeruhan dan timbulnya gas dalam media Lactosa Broth singgle Strength dan Lactosa Broth Triple Strength.

b) Uji Penegasan
1. Disiapkan media BGLB (Briliant Green Lactose Bile Broth) sebanyak tabung gas yang positif pemeriksaan pendahuluan.

2. Ose disterilkan pada pembakar spirtus

3. Diambil 1-3 ose dari tiap-tiap tabung gas positif, kemudian di inokulasikan ke tiap tabung BGLB.

4. Diinkubasikan pada suhu $44^{\circ} \mathrm{C}$ selama 24 jam.

5. Diamati kekeruhan dan timbulnya gas pada media BGLB kemudian dicocokkan dengan tabel MPN 511 menurut formula Thomas.

d. Prosedur Pemeriksaan Kualitas mutu

Pemeriksaan kualitas mutu (Rasa, Rupa, bau, Warna, dan Tekstur) dilakukan dengan pengamatan langsung secara makroskopis kemudian dilakukan perbandingan dengan standar mutu yang telah ditetapkan (SNI, 2009).

e. Prosedur Penetapan Jumlah Bakteri (ALT)

Setiap kelompok sampel dilakukan penetapan jumlah bakteri.

Prosedurnya adalah :

1) Pengenceran sampel

a) Masing-masing sampel ikan pindang ditimbang sebanyak 10 gram dalam labu Erlenmeyer steril, kemudian ditambah larutan $\mathrm{NaCl}$ fisiologis sampai volume $100 \mathrm{ml}$. Didapatkan pengenceran 10 kali.

b) Membuat pengenceran larutan ikan pindang 100 kali, 1000 kali, dan 10000 kali dari pengenceran 10 kali.

1. Pengenceran 100X : $9 \mathrm{ml} \mathrm{NaCl} 0,85 \%+1$ $\mathrm{ml}$ bahan pengenceran $10 \mathrm{X}$.

2. Pengenceran 1000X : $9 \mathrm{ml} \mathrm{NaCl} \mathrm{0,85 \% +}$ $1 \mathrm{ml}$ bahan pengenceran $100 \mathrm{X}$.

3. Pengenceran 10000X : $9 \mathrm{ml} \mathrm{NaCl} \mathrm{0,85 \% +}$ $1 \mathrm{ml}$ bahan pengenceran 1000X.

2) Inkubasi pada media Plate Count Agar

a) Petri dish steril diberi $1 \mathrm{ml}$ bahan dari pengenceran 10X, 100X, 1000X, dan 10000X.

b) Media Plate Count Agar (PCA) cair dituang ke dalam petri dish yang telah berisi bahan lalu diputar melingkar dengan pelan agar homogen.

c) Setelah media beku, diinkubasi selama $2 \times 24$ jam pada suhu $37^{\circ} \mathrm{C}$.

3) Perhitungan jumlah angka kuman

a) Koloni yang tumbuh dihitung secara manual dengan member tanda menggunakan spidol pada cawan petri atau dapat pula dihitung dengan menggunakan alat coloni counter. 
b) Hasil atau jumlah koloni yang dipakai atau dilaporkan sesuai dengan Standart Plate Count (SPC).

Perhitungan Koloni

1. Idealnya jumlah koloni per plate yang boleh dihitung antara 30-300 CFU (Colony Form Unit).

2. Koloni besar, kecil, menjalar berasal dari satu bakteri.

3. Perhitungan dapat dilakukan secara manual dengan memberi titik dengan spidol pada petri dish bagi koloni yang sudah dihitung, dapat juga menggunakan colony counter.

4. Tiap - tiap plate dari pengenceran berbeda dihitung jumlah koloninya.

c) Jumlah angka kuman dihitung dengan rumus perhitungan Jumlah angka kuman

$((\Sigma-\mathrm{C}) \times 10)+((\Sigma-\mathrm{C}) \times 100)+((\Sigma-\mathrm{C}) \times 1000)$

\section{$\mathrm{P}$}

$\Sigma$ : Jumlah koloni bakteri

$\mathrm{P}$ : Pengenceran

$\mathrm{C}$ : Control bakteri

d) Pengulangan dilakukan sebanyak 3kali kemudian dilakukan rata-rata hasil (BPOM RI, 2008).

\section{ANALISA DATA}

Analisa data hasil penelitian dilakukan secara deskriptif, yaitu menggambarkan hasil yang didapat dalam bentuk tabel atau grafik dengan berpedoman pada SNI Ikan Pindang tahun 2009

\section{HASIL DAN PEMBAHASAN}

Sampel ikan pindang layang diambil secara acak dari 6 tempat di Pasar Mambal. Setiap tempat masing-masing diambil 5 sampel Ikan pindang layang. Sehingga total jumlah sampel adalah 30 sampel. Pada pemeriksaan metode MPN menunjukkan hasil positif uji pendugaan pada semua sampel ikan pindang. Hasil positif tersebut ditanam pada media Brillian Green Lactose Broth sebagai uji konfirmasi dan didapat hasil positif adanya Escherichia coli pada semua sampel yang diperiksa. Selanjutnya ikan pindang dihitung jumlah bakterinya dengan metode ALT. Jumlah kuman yang dihitung dengan metode hitungan cawan pada media Plate Count Agar (PCA). Hasil penelitian kualitas mutu (Rasa, Rupa, bau, Warna, dan Tekstur) dari 30 sampel ikan pindang layang di Pasar Mambal, Badung, Bali menunjukkan hasil yang baik

Dari 30 sampel yang diperiksa diperoleh jumlah MPN Escherichia coli melebihi nilai standart kualitas ikan pindang dari SNI 01-27172009 (Tidak memenuhi syarat). Jumlah MPN Escherichia coli ikan pindang di bawah nilai standart maximum yang di ijinkan oleh SNI 012717-2009 yaitu < 3 APM/gram (memenuhi syarat). Pemeriksaan dengan menggunakan MPN adalah untuk menentukan bakteri Escherichia coli dengan melewati uji pendugaan dan konfirmasi. Seri $44^{\circ} \mathrm{C}$ adalah uji untuk menentukan jumlah bakteri Escherichia coli karena adanya zat Brilliant Grameen dan diinkubasi pada suhu $44^{\circ} \mathrm{C}$ dapat menghambat pertumbuhan bakteri lain kecuali Escherichia coli.

Penelitian dari ikan pindang dengan metode MPN pada media Lactose Broth di dalam tabung dapat berubah warna menjadi keruh hal tersebut disebabkan oleh terbentuknya asam dan gelembung gas pada tabung durham. Semua tabung positif pada media Lactose Broth diinokulasi pada media Brilliant Green Lactose Broth dan didapatkan hasil positif pada semua tabung. Hasil positif pada media Brilliant Green Lactose Broth ditandai dengan terbentuknya gas pada media yang digunakan dalam uji konfirmasi. Hal tersebut menunjukkan bahwa dalam ikan pindang yang digunakan sebagai sampel penelitian mengandung Escherichia coli.

Escherichia coli merupakan flora normal usus digunakan sebagai indikator pencemaran tinja pada air minum, kolam renang, makanan, dan minuman. Jenis bakteri ini paling sering menyebabkan penyakit infeksi pada saluran cerna (Irianto, 2013). Bakteri ini dapat hidup dalam usus besar manusia dan hewan, dalam tanah, dan dalam air. Karena hidup dalam usus besar manusia, bakteri-bakteri ini sering disebut dengan bakteri enterik (Radji, 2009). Pencemaran E.coli kemungkinan dapat berasal dari air yang digunakan untuk mencuci ikan pindang ataupun kebersihan lingkungan tempat penjualan ikan pindang tersebut. pekerja setelah buang air besar tidak mencuci tangan dengan menggunakan sabun atau bahan disinfektan lainnya. Kemungkinan lain pekerja memegang ikan pindang setelah buang air besar dan tidak mencuci tangan dengan menggunakan sabun atau bahan disinfektan lainnya.

Pada penelitian ini digunakan juga metode Angka Lempeng total yang bertujuan untuk menghitung nilai Angka Lempeng Total 
keseluruhan bakteri suatu bahan. Pengujian ini dilakukan dengan menanam bahan pada beberapa pengenceran kemudian ditanam pada media agar dan diinkubasikan pada suhu $37{ }^{\circ} \mathrm{C}$ selama 2 × 24 jam. Nila Angka Lempeng Total didapat dengan mengamati koloni secara visual dan dihitung koloni bakteri pada plate secara manual dengan memberi tanda menggunakan spidol. Keuntungan dari metode pertumbuhan agar atau metode uji Angka Lempeng Total adalah dapat mengetahui jumlah mikroba yang dominan. Keuntungan lainnya dapat diketahui adanya mikroba jenis lain yang terdapat dalam contoh.

Pada pemeriksaan Angka Lempeng Total juga ada didapat hasil yang melebihi batas maksimal yang ditentukan pada SNI 01-2717-2009 dimana batas maksimal yang diperbolehkan yaitu 5 x $10^{5} \mathrm{CFU}$ per gram bahan. Ikan pindang layang yang diperiksa tidak memenuhi syarat dapat disebabkan oleh pembusukan pada ikan pindang. Pembusukan dapat terjadi akibat lamanya waktu penyimpanan hingga batas layak konsumsi dimana pada umumnya ikan pindang apabila ditangani dan disimpan dengan baik dapat bertahan hingga 2 sampai 3 hari. Selama penyimpanan mutu ikan pindang dapat menurun. Pembusukan pada ikan pindang disebabkan oleh kandungan air dan protein yang tinggi, serta $\mathrm{pH}$ tubuh ikan mendekati netral dimana kondisi tersebut merupakan media yang baik untuk pertumbuhan bakteri pembusuk dan mikroorganisme lain.

Pengujian kualitas mutu (Rasa, Rupa, bau, Warna, dan Tekstur) dari ikan pindang layang di Pasar Mambal, Badung, Bali menunjukkan hasil yang baik. Menurut Suwamba, (2008), beberapa sifat atau keadaan yang dipakai untuk menetapkan kualitas atau mutu pindang yang baik adalah Warna pindang putih keabu-abuan, Permukaan kulit menjadi keset, Ikan tidak patah-patah tetapi dalam keadaan utuh, Tidak terlihat adanya lendir bakteri maupun kapang, Flavour yang menunjukkan kesegaran pindang

\section{KESIMPULAN}

Ikan pindang layang yang diperiksa memiliki kualitas mutu (rasa, rupa, bau, warna, dan tekstur) yang tidak baik dan tidak memenuhi syarat sesuai
SNI 01-2717-2009 yang menyatakan bahwa jumlah bakteri Escherichia coli dalam ikan pindang adalah < 3 APM per gram bahan dan jumlah maksimal ALT ikan pindang adalah $5 \times 10^{5}$ CFU per gram. Ikan pindang layang yang diperiksa kulitas mutunya (Rasa, Rupa, bau, Warna, dan Tekstur) memiliki kualitas yang baik.

\section{DAFTAR PUSTAKA}

Badan Pengawas Obat dan Makanan RI., 2008. Pengujian Mikrobiologi Pangan. Jakarta.

Darmanto Y.S., 2001. Pengetahuan manajemen mutu dan teknis pengolahan hasil perikanan. Fakultas perikanan kelautan. UNDIP. Semarang.

Irianto, K., 2013. Mikrobiologi Medis (Medical Microbiology). Alfabeta, Bandung.

Radjie, M., 2009. Buku Ajar Mikrobiologi Panduan Mahasiswa Farmasi \& Kedokteran. EGC, Jakarta.

Santoso, H.B., 2006. Teknologi Tepat Guna : Ikan Pindang. Kanisius. Yogyakarta.

SNI., 2009. Standar Nasional Indonesia 01-27172009 Tentang Ikan Pindang.

Suwamba, I Dewa Ketut., 2008. Proses pemindangan Dengan Mempergunakan Garam dengan Konsentrasi yang berbeda. http://www.smpsaraswatidps.sch.id/artikel/3. Diakses 4 Februari 2014.

Winarni, T., Swastawati, F., Darmanto, Y. S., dan Dewi, E. N., 2003. Uji Mutu Terpadu pada Beberapa Spesies Ikan dan Produk Perikanan Di Indonesia. Laporan Akhir Hibah Bersaing XI Perguruan Tinggi. Universitas Diponegoro, Semarang.

Wirakusumah, E.P., 2010. Sehat Cara Al-Qur'an dan Hadis. Hikmah, Jakarta. 